\title{
Linguistic Education Under Revision: Globalization and EFL Teacher Education in Brazil
}

\author{
Ana Rachel Mendes \\ Post-Graduate Program of Linguistics, Federal University of Espirito Santo \\ Av. Fernando Ferrari, 514 - Goiabeiras, Vitória, ES, Brazil \\ Tel: 55-27-99994-4132Ｅ-mail: anarachel.mm37@gmail.com
}

Kyria Rebeca Finardi (Corresponding author)

Post-Graduate Program of Education and of Linguistics, Federal University of Espirito

Santo

Av. Fernando Ferrari, 514 - Goiabeiras, Vitória, ES, Brazil

Tel: 55-27-99299-0058Ｅ-mail: kyria.finardi@gmail.com

Received: January 13, 2018 Accepted: Mach 14, 2018 Published: March 16, 2018

doi:10.5296/elr.v4i1.12831ＵRL: http://doi.org/10.5296/elr.v4i1.12831

\begin{abstract}
Globalization brought about many changes to the current society's life and mindset and thus, some new challenges to linguistic education, more specifically, foreign language education, have emerged as a consequence of these changes. This paper aims at reflecting upon some impacts of globalization on pre-service English as Foreign Language (hereafter EFL) teacher education in Brazil. Based on the literature review, the paper addresses the changes in the concepts of language, culture and identity related to cultural hybridity and the impact of new information and communications technology on the use, teaching and learning of foreign languages. It concludes that curricula for EFL teacher education programs in Brazil should be reviewed in order to focus more on glocal knowledge and digital literacy for a 21 st century aligned education.
\end{abstract}

Keywords: Globalization, Linguistic education, English teacher education, New information and communications technology, Hybridity 


\section{Introduction}

Globalization can be defined as the flow of technology, economy, knowledge, people, values and ideas between borders (Knight \& de Wit, 1997). Even though some scholars have identified it since the 16th century colonial period, Kumaravadivelu (2006) says that, depending on how it is understood, globalization can be considered as old as humanity. According to him, generally speaking, social studies have seen this phenomenon basically through three different lenses: i) westernization of the world; ii) cultural battle against local and global tensions; and iii) the intertwining and interdependence of global and local contexts. Through the latter perspective, which will be considered for this article, globalization has proven to be an extremely complex process whose repercussions have been developing rhizomatically (Note 1) throughout economic, political and socio-cultural domains and as such, impact language use, teaching and learning in general and foreign (English) language education in particular.

Although this paper focuses mainly on some of globalization socio-cultural effects, we find it important to mention some of its implications in the world's economy and politics. According to Appadurai (2000), globalization can be primarily related to capital's global traffic which flows in the same logic as imperial ages, attempting to prey local economies. It has been called "runaway horse without a rider" (Appadurai, 2000, p. 16) due to its independence from "traditional constraints of information transfer, national regulation, industrial productivity, or 'real' wealth in any particular society, country, or region" (p. 3) and to the implications of this "chaotic, high velocity, promiscuous movement of financial (especially speculative) capital" (p. 4). Appadurai (2000) claims that local capacities to deal or stand against the global capital's "predatory mobility" have become compromised and States have been seen as its instruments. For that reason, the author suggests looking at globalization through a more political optic considering how unstable the concept of nation-state has become due to its "floating populations, transnational politics within national borders, and mobile configurations of technology and expertise" (Appadurai, 2000, p. 5), each of which behave and interact differently to affect local situations. "Indeed, it is the disjunctures between the various vectors characterising this world-in-motion that produce fundamental problems of livelihood, equity, suffering, justice, and governance" (Appadurai, 2000, p. 5). Thus, Appadurai (2000) states that globalization means "a world of disjunctive flows-produces problems that manifest themselves in intensely local forms but have contexts that are anything but local" (p. 6).

Similarly, Rassool (2007) explains that financial and cultural exchanges between people and countries, reinforced by fast communication promoted by the new technologies, have resulted in a more dynamic and interactive global economy. However, countries and people that do not have the necessary social and cultural capital to join these exchanges have become outsiders once "the emergence of global political, cultural and economic networks, practices and institutions have transformed the distribution, organization and exercise of power" (Rassool, 2007, p. 101). In that sense, Moita Lopes (2006) argues that globalization reveals its perverse aspect by being responsible for poverty, social injustice and marginalization of all those who do not share the same hegemonic ideology conveyed by the implicit discourse of a standardizing power, hence the term "globalization" aiming to comprise everyone (Note 2). 


\section{Ml Macrothink}

Nonetheless, Finardi, Santos and Guimarães (2016) and Finardi (2016) in reference to Blommaert's (2010) and Bourdieu's (1991) point of view on globalization, claim that this phenomenon needs to be considered in its complexity, not being binarily categorized as either positive or negative but rather as a "double-edged sword". While globalization allows hegemonies to establish networks to reinforce their power, it can also promote resistance strategies for this dominance, especially in the infoera (Lévy, 2000) characterized by an ample array of possibilities for information access. Due to weaker geographical/temporal borders and greater contact among cultures, the use of digital communication can lead to a diversification of discourses (Kumaravadivelu, 2006) and more access and voice to millions of people (Finardi \& Porcino, 2014), thus resulting in a counter-hegemonic force. Kumaravadivelu (2006) suggests the term "glocalization" (Note 3), coined by sociologist Roland Robertson to refer to global and local interrelations, transforming each other, influencing how each individual sees oneself, the other, and the world. Glocalization is permeated by a dialogical process, in which local events can be defined by other global events, and vice versa, creating other narratives beyond the hegemonic ones.

Appadurai (2000) sees top-down globalization as a process which increases gaps between the few at the top who set global rules and the majority at the bottom who have to live by those rules. On the other hand, "grassroot globalization" or a "globalization from below" can have different effects once it contests and attempts to reverse the authority of those at the top on behalf of the marginalized ones. However, the author points out that efforts to counteract top-down globalization are yet to generate many impacts globally, which is why new pedagogies are needed to promote critical thinking and collaboration in order to "democratize the flow of knowledge about globalization itself" (Appadurai, 2000, p. 18). In this context, new aspects are introduced in the school's local reality bringing about new challenges to education to consider culture through a glocal perspective, especially related to language due to its important role in global communication and information flow. In Brazil, Finardi (2014) claims that this can be achieved by appropriating the international language, English, using it for and through glocal needs/perspectives. We will return to this issue later on in this paper.

Rassool (2007, p. 142) argues that "world languages" have emerged in international communication official and public contexts and have mainly been represented by the English language. It is a fact that English has been spreading through the world allowing transnational communication, but Rassool (2007) highlights it is important to perceive that this predominance has its roots in British colonialism, where colonizers imposed their language to the public spheres of colonized societies. Thus, he claims that English was the official language for economic, social and institutional participation and regional languages were kept mainly for private interaction. Therefore, English was a requirement for high social status and shaped colonization by delegitimizing regional languages.

Despite the fact that the British colonial period was officially over in the 19th century, English predominance continues to gain strength in the global society. Crystal (2003) also recognizes colonial heritage as one of the reasons for the expansion of English though he points out that the primary explanation for the current status of English as "global language" is the rising of the United States as the leading economic power by the beginning of the 20th century. According to the author, coincidentally at that time, new opportunities for the 
language to be spread appeared alongside new technologies and with that, the US also expanded its cultural (through media), economic and political power (through international alliances). Nevertheless, Crystal (2003) states that the English status as "world language" was only genuine after the political independence of new English-speaking countries and, most recently, after electronic revolution.

Besides "world language" and "global language" other terms have been associated with English: "lingua franca" (Jenkins, 2007), "academic lingua franca" (Jenkins, 2013), "international language" (Finardi, 2014) and "internet language" (Paiva, 2001). Regardless of how it is seen, English as foreign language (EFL) education needs to consider the social, cultural, economic and linguistic consequences of its predominance, not only as a matter of communication, but also as a matter of power. Mattos (2015) highlights that English has taken different roles in each community and depending on the status given, it can be used as a tool to oppress localities by imposing hegemonic ideologies. Regarding the use of English in Brazil, Finardi and França (2016) show how this language can affect the impact and circulation of the academic production of that country and Finardi (2014) also warns us that the international status of English, if taken as a linguistic imperialism with its symbolic and hegemonic power, may create a social gap between those who have access to it and those who do not.

On the other hand, Cope and Kalantzis (2000) refer to an English role paradox in the global world: at the same time it is used as the language for international political, economic and cultural exchanges, it is also developing into "multiple englishes", that is, several varieties of English in different locations and by different people. Again, regarding the teaching of English in Brazil, Finardi and Ferrari (2008) claim that it is important to bear in mind which English is taught, learned and used in that country and for which purposes.

Warschauer (2003) points out that the globalization of English has happened in two stages. First, the language has reached new domains worldwide. Then, it has been relocalized in order to best meet each community's interests. An evidence of this is that speakers of EFL have outnumbered native speakers of English, and as a result, "speakers of English will use the language less as an object of foreign study and more as an additional language of their own to have an impact on and change the world" (Warschauer, 2003, p. 530). However, in order for this empowerment to take place, EFL education must be focused on agency so that students may be able "through English, to impose their voices on the world" (Warschauer, 2003, p. 530).

Accordingly, Ferraz (2010) proposes educating through the additional language by addressing sociocultural issues such as identity, culture, citizenship and their intertwining as well as through the teaching of linguistic aspects. For the aforementioned author, it is possible to contribute to students' agency by expanding the teaching of additional languages beyond language training towards a socio-cultural dimension (Ferraz, 2010). In the same vein, Monte Mór (2009) suggests considering a more coherent education focusing less on methodologies and more on reflective practice which includes the rethinking of one's pedagogies and philosophies and new possibilities for knowledge construction.

For this reason, we propose a reflection on the need to rethink EFL teacher education in a 
local context (Brazil) to drive English teaching beyond linguistic and instrumental aspects and towards a linguistic education that takes on the challenge to prepare glocal citizens in a constantly changing culturally and linguistically hybrid digital society (Ferraz, 2010; Monte Mór, 2009). To this end, we start this article by addressing socio-cultural aspects that arise from globalization and that affect language education before considering EFL teacher education in the current glocal scenario in Brazil.

\section{Cultural Hybridity}

One of the most noticed features of globalization is how it has been erasing geographical borders allowing for people, ideas, information and goods to flow rapidly across the globe in an intense interconnectivity (Kumaravadivelu, 2006; Mattos, 2015) - either virtually (with digital communication and the increase of social networks) or physically (as recent mass migration and refugeeism) - that may lead to the hybridization of cultures. Canclini (2008) optimistically sees hybridity as the merge of cultural processes that brings about new practices, objects and structures. Burke (2003) also finds the creative and innovative aspect of cultural hybridity positive as it promotes opportunities for new narratives, which may differ from western hegemony by looking through the eyes of peripheral cultures (Bhabha, 2013).

However, hybridity is not always seen as the "encounter" or blending of cultures. Cevasco (2006), for one, suggests that a consequent blending of cultures should be avoided because it threatens national identities or, as Burke (2003) points out, it leads to the weakening and even disappearance of local and regional traditions. Thus, hybridity could become a disguise used by hegemonic cultures to indoctrinate their ideologies and subordinate minorities (Kern, 2011). On the other hand, 'subordinates' can subvert hegemonic culture as they take advantage of the inherent diversification of cultural hybridity in order to empower themselves (Bhabha, 2013) creating a conflict between two different cultures. According to Bhabha (2013), the hybrid discourse arises when the colonized seeks to be perceived by challenging the hegemonic discourse demanding recognition for their own culture.

Rather than an encounter or conflict, Hall (2013) thinks hybridity as the negotiation between different cultures and this is the perspective some applied linguistics seem to have on that matter as well. For example, Fabrício (2006) believes that the crossroad among several epistemologies, ideologies, cultures, identities, subjectivities, discourses and power relations does not need to represent opposition, but rather a fluid and continuous exchange that contributes to an ecology of knowledge (Santos, 2007). This epistemology can be related to the notion of border thinking proposed by Mignolo (2003), as well as to the notion of linguistic education suggested by Monte Mór (2009). What these authors have in common is the defying of binary views of the modern world that seek to standardize knowledge by erasing and silencing the other. Likewise, Rojo (2009) believes that this cultural hybridity must be addressed by educators in order to bring local cultures literacies into contact with universalized ones in order to listen to silenced narratives (Moita Lopes, 2006; Bhabha, 2013). Also, she suggests education should foster a counter-hegemony power to rethink Western global standardized mindsets that ignore and destroy other ways of knowledge construction and social practices.

Thus, we understand that the space provoked and afforded by the contact and/or conflict 


\section{MInstitute Macrothink $_{\text {Int }}$}

between different cultures, practices, discourses and ideologies allows a dialogue that contributes to the valuing of diversities, deconstructing power relations and prejudices (Rojo, 2009). From this encounter, all aspects are transformed, re-transformed and combined in a cyclical and constant movement, culture- and identity-wise. A more coherent linguistic education proposes the articulation of different voices in order to capture the complexity of this process, resounded in discourses, in order to deconstruct premises, thus suspending truths (Ferraz, 2010; Monte Mór, 2009). In order to do so, we must take into account not only cultural hybridity but also the new social dynamics of informationalism.

\section{New Information and Communication Technologies}

Another important characteristic of globalization is the increased access to information and knowledge provided by the internet (Appadurai, 2000). Indeed, Warschauer (2003) posits that informationalism is the "new global economic order" (p. 512) based mainly on "the application of science, technology, and information management as the key elements of productivity and economy growth" (p. 512). As a result, the new information and communication technologies (NICT), or the "21st century technologies" according to Ferraz (2014) have become intrinsic in current society and have changed our way of acting and interacting (Finardi \& Porcino, 2014). In fact, the fast and easy flow of information allowed by NICT enables millions of people to connect to the internet on a daily basis and for a variety of reasons. In Brazil there are more than 110 million online users and as reported by Finardi and Porcino (2016), Brazil is the second largest user of Facebook, a social network website. According to the aforementioned authors, internet has increased access to information to the same extent that social networks have increased opportunities for citizens to express themselves in their communities, as shown in the street demonstrations organized through Facebook that broke out in Brazil in 2013 and which continue to this day.

By observing the social changes brought about by the new digital technologies, we wonder how they have been transforming the human brain, creating new forms of knowledge and learning. Bohn (2013) describes some of the shifts NICT have brought to the process of knowledge building, including the vast arrays of tools and content available online. Attention span has decreased mainly because of the excess of information available in the infobesity era, or the era of the excess of information. Also, the easiness and readiness in which information can be found online has shown to impact how it is processed in our minds. Certainly, this data overload causes changes in the way we think as scientific evidence demonstrates that, due to its plasticity, the brain has the ability to reorganize itself throughout our lives, regardless of age (Nicolelis, 2011).

Regarding how the brain organizes itself, Prensky (2001) draws attention to the fact that children who were brought up in environments with computers think differently from those who grew up in computer-free contexts. According to him, these 'digital natives' have developed nonlinear, fluid minds and find it hard to think in a more static or linear way. Castells (2016) names current society epistemology "network mind" as opposed to the "typographic mind" of the pre-digital era.

The metaphor of the network $\mathrm{x}$ typographic mind is used to explain how these two types of mind process visual information differently. Regarding how we process texts, Bohn (2013) 
claims that the hypertext reader builds the text as desired, going from one page to another through hyperlinks. In this kind of nonlinear hypertext reading, identifying who the author and the reader are may represent a challenge. Hence and referring to the web 2.0, Finardi and Porcino (2016) relate to the idea of "produsage" introduced by Bruns (2006) to describe the blurring of borders between users and producers of information online. The aforementioned authors link this idea with that of teaching and learning intertwined in the digital age where the roles of teacher and learner are also mingled and blurred.

Regarding the processing of information in the digital society, we can say that there is no time to ponder over what one is reading in the infoera characterized by the overload of simultaneous information (Bohn, 2013). The lack of time to process information can affect its transformation into knowledge and learning. Prensky (2001) defines reflection as the ability to generalize and learn from experience, a skill that needs to be developed in "digital natives" in order to critically exercise their citizenship.

Another change brought about by NICT is the fact that the medium has become more important than the content. In other words, the channel used to send a message has greater impact on the way we think and respond to the message than the content of the message itself (2006). This may be partially explained by the plethora of means available today for communication. Monte Mór (2012) highlights the focus on multimodality as one of the shifts in society that echoes through life and relationships. Language and meaning are constructed using different means and modes. Lankshear and Knobel (2003) present the term "digital epistemology" or "performance epistemology" for the transdisciplinary knowledge that is necessary in today's society. Such way of meaning-making takes place in situations under which related knowledge has not yet been envisioned yielding the need to learn to act without previous models. Thus, digital epistemology focuses on performance, which differs from content-based school subjects.

As mentioned earlier, NICT, particularly the internet, has expanded access to information (Finardi, Prebianca, \& Momm, 2013) and education (Finardi \& Tyler, 2015) online. However, a large part of the world's population still does not have access to these new technologies and does not speak (enough) English to extend this access. Therefore, they are marginalized by the lack of technological and linguistic resources. Just as globalization, NICT empower some people at the expense of excluding others, causing the so-called digital divide (Rada, 2004) or the digital gap (Warschauer, 2004). Nevertheless, availability of tools is not the only requirement for being part of the information society and according to Warschauer (2003, 2004) there are two types of access to technology. The author talks about the availability of technological tools and pieces as a type of narrow access that may not in itself impart benefits for users. The other type of access described by Warschauer is the broad access which includes not only the availability of tools and technological gadgets but also and most importantly, the critical use of these tools. Warschauer $(2003,2004)$ claims that only the broad access to NICT can lead to the formation of social capital.

Social capital is a concept introduced in contemporary sociological discourse by Pierre Bourdieu (Portes, 2000) to refer to the symbolic value a social network can provide to yield benefits for an individual or a community. According to Bourdieu, this value is a result of the resources obtained through these relationships and their numbers and quality as it is also the 
basis for the creation and maintenance of these solidary networks (Portes, 2000). More recently, Robert Putnam has expanded the range of social capital to reach broader social structures, such as cities, states and countries, giving them a more civic role (Portes, 2000). For Putnam, social capital must be understood as a feature of social structures used to promote mutually beneficial cooperation (Portes, 2000) developed in personal relations among family and community members, in moral obligations and norms and in social values (Warschauer, 2003). For that reason, by having broader access to technology and networks, individuals can engage in digital practices becoming familiar with contemporary values such as collaboration, in order to exercise a more active citizenship. Thus, social capital, as the possibility of yielding benefits for one's own or for one's community as a consequence of one's action in a social network is optimized by the access to and critical use of technology (Warschauer, 2003).

As a consequence, efforts must be made in order to provide technology access, narrow and broad, for all and in different registers/languages, though as shown by Finardi and Tyler (2015) in the analysis of MOOCs available per area and per language, this is not always the case. Finardi, Prebianca and Momm (2013) claimed that some knowledge of English and some digital literacy was necessary to access information online and Finardi and Tyler (2015) corroborated this assumption by showing that most $(83 \%)$ of the MOOCs available are in English which means that access to education online is also limited by the language one masters and the digital literacy and tools one has available.

Regarding language education, an extremely important aspect is how NICT empowers new literacy practices. Digital technology can be used to do the same things we used to do but in different ways. NICTs have brought about new forms of responsiveness such as real time online interaction and collaborative production, social networking, cloud storage, virtual reality and so on. Ferraz (2014) mentions that the new literacies movement emphasizes technologies as well as mindsets from this digital era. According to the author, this movement deals with the tension between real and virtual as well as with collectively and contextually built knowledge.

Likewise, Lankshear and Knobel (2007) highlight the collaborative nature of everyday social practices as one of the main characteristics of the so-called Web 2.0. This kind of collaboration decentralizes social practice including individuals without hierarchy. Other features of the Web 2.0 are users' reciprocity and collaboration. For example, it is common to find videos available to the public in which people share their knowledge, teaching whomever is interested in the topic through videos and tutorials. This new mentality fosters greater support and cooperation within the digital community where cooperation is more important than competition (Lankshear \& Knobel, 2007) and where it is difficult to draw a line separating consumer from producer (Bruns, 2006), teacher from student (Finardi \& Porcino, 2016) and author from reader. All of these shifts in global society are intensified by internet omnipresence which also affects the way culture and identity are understood.

\section{New Concepts for Language, Culture and Identity}

Due to the many forms of representation offered by digital technologies and cultural hybridity, language is no longer seen as merely verbal expression (Duboc, 2015). The concept of 
language has been expanded to include new kinds of languages and more comprehensive and complex forms of meaning-making. Multimedia allows for these forms to multiply and reinvent themselves in such a way that traditional views of language are defied (Bohn, 2013). Language is now conceived as hybrid, versatile and mutant especially due to the collaborative aspect of the meaning-making process which has gained new dimensions in the digital age (Bohn, 2013; Duboc, 2015; Canagarajah, 2005). In such era, individuals find themselves in a more public and less controlled environment which allows them to create meaning and take part in social actions more actively.

Furthermore, language is also regarded as a representation of ideologies, not only as a communication tool (Mattos, 2015). This ideological aspect of language is emphasized by Bohn (2013) who regards it as a social and discursive practice which can never be neutral, for the choice of a certain discourse always involves the choice of an underlying ideology. Thus, the ideological and mutant nature of language leads us to understand it as an agent that transforms social context while it is also transformed by it (Canagarajah, 2005).

Also, these are times of intense cultural contact where no one lives isolated and where cultures and languages are hybrid and deterritorialized (Canagarajah, 2005), for they are not restrained to national and local limits, instead, they are extended to transnational and global settings in various intersections through which the local meets the global and vice-versa (Cooppan, 2004). In this encounter, there may be a strengthening of local identities as a counterpoint to emerging new global identities (Hall, 1992) - we have witnessed these discourses lately in the nationalistic speeches of Donald Trump and the Brexit voters.

At the same time, the notion of a homogeneous national cultural identity conveyed by a hegemonic discourse is being deconstructed as cultural diversity subverts it (Bhabha, 2013), specially with multicultural discourses invigorated through mass digital communication technologies and the broadening of the "restricted" access to it. As it is, the very conception of culture is undergoing an identity crisis. Hall (1992) claims that a fully unified, completed, secure, and coherent identity is a fantasy. According to him, identity can be seen as the sense of oneself that an individual has as part of a group and the understanding of how it is formed has changed over time. In the past, it used to be defined by illuminists as the essence with which the individual was born with. Later on, it was accepted that this essence was transformed constantly by social interactions in order to integrate the individual to the cultural world. More recently, as the systems of meaning and cultural representation multiply, we are confronted by a bewildering, fleeting multiplicity of possible identities, any of which we could identify with - at least temporarily (Hall, 1992, p. 277). So, in postmodern society, identity has been seen as historically defined rather than essentially biological, and as "identities" that may be constructed, deconstructed and reconstructed as they cross with others rather than as a homogeneous one (Hall, 1992). In Bauman's (2005) view of the "liquid society", everything is temporary and characterized by constant changes, nothing is stable, not even identities. Cultural contact has disrupted the traditional idea of national identity whereby a subject speaks a particular language and comes from a specific nation (Mattos, 2015). Similarly, Bohn (2013) states that cultural identity is no longer defined by the nation, religion or social class. In addition, Pennycook (2006) argues that identities are not pre-given 
but are formed in the linguistic performance.

These new views of language, culture and identity as continuous constructions in contact with the 'other' call for a redesign of linguistic education (Monte Mór, 2009). To that end, it is important to highlight the need for an 'epistemology of incompleteness' in which we must be aware of our own 'cultural incompleteness' before trying to emancipate a multicultural appreciation of human rights (Santos, 2006, p. 446). In other words, it is essential to consider ourselves as unfinished beings, still under construction (Freire, 2011) as we seek alterity in facing the challenge of respecting differences by integrating them so as to enhance them rather than neglect them (Fleuri, 2003). Bringing this to practice is extremely challenging especially in the context of the EFL classroom. The deconstruction of Freire's 'banking' view of education, language, and of oneself is central to this liberating praxis (Freire, 2011). Another important characteristic of globalization is the increased access to information and knowledge provided by the internet (Appadurai, 2000).

\section{English as Foreign Language Teacher Education in and for the 21st Century}

Considering the aforementioned tensions brought about by globalization with the consequent hegemony of English, we posit that EFL teacher education in and for the 21 st century must be reviewed so as to understand and reflect culture, language and identity and also the new forms of communication and technology afforded by this new era. However, before we delve into that goal, we find it necessary to further discuss how globalization has affected EFL education worldwide.

In recent years, it has become "common sense" to consider English as a key requirement for personal or national economic development and for that reason its teaching has become part of basic education around the globe (Erling \& Seargeant, 2013) where institutions in Europe and Asia, such as in Turkey (Taquini, Finardi, \& Amorim, 2017) include the teaching of and through English in all levels of education. In addition, many European countries have adopted Content and Language Integrated Learning (CLIL) whereby the language of instruction is English, for basic education, in order to promote multilingualism, and English Medium Instruction (EMI), in universities as an internationalization strategy (Casotti \& Finardi, 2016).

Despite its emphatic importance to engage in global economy and access information and knowledge opportunities (Finardi et al., 2013; Erling \& Seargeant, 2013), researchers have found the relationship between English and economic development is not as straight-forward as it is believed (Erling \& Seargeant, 2013). That is because the link between language education and economic advancement is permeated by a myriad of contextual social variables that also need to be taken into account. In that regard, some researches argue that, in post-colonial societies, relying on English as official language, at the cost of ignoring local languages, has affected the country's potential for development (Erling \& Seargeant, 2013).

In fact, the view of English as a lingua franca or as an international or global language related to economic development is ideologically charged and thus has potential symbolic power (Rassool, 2007). For that reason, some scholars see the promotion of EFL around the globe as linguistic imperialism and even as a form of genocide (Warschauer, 2003). Casotti and 
Finardi (2016) suggest that hegemonic discourses (and speeches, accents) can often try to erase the less prestigious dialects. EFL education must acknowledge the fact that languages carry a set of ideologies, values and norms based on their history, development and use (Warschauer, 2003) that have led to the extinction of indigenous languages, privileges for some and exclusion for many others. Warschauer (2003) agrees with this stance and has a fatalistic view of EFL denying the benefits it can bring as agency. In fact, considering national and additional languages as complementary rather than opposed to each other to foster multilingualism throughout all educational life seems more beneficial for individuals and glocal communities although language policies are required to guarantee this peaceful coexistence of languages (Erling \& Seargeant, 2013).

Portuguese is the only official language in Brazil (Note 4), even though the country is surrounded by Spanish-speaking nations and has several communities in which immigrant and indigenous languages are considered the mother tongue, making it a multilingual country (Finardi, 2017). As a result, Finardi (2017) believes language policies should ensure that Brazilians learn, besides the recognized official language, their neighbor's language (Spanish), the international language (English) and also their heritage languages. However, it seems that promoting such a multilingual education is far from viable by looking at Brazilian language policies (Finardi, 2017) starting from the fact that the term "foreign language", the term used in Brazilian documents to refer to any language but Portuguese, implies that the foreign language belongs to the "foreigner", and thus cannot be critically appropriated and transformed but only reproduced as the "foreigner's language" (Finardi, 2014). According to Brazilian public school legislation, a "foreign language" subject must be provided in the upper levels of primary education and even though schools could choose what language to teach, English has been the most chosen language (Finardi \& Tyler, 2015). This legislation has been changed however and the teaching of English as a foreign language is mandatory as of 2017. We believe that this change in language policy reflects the government's goal to improve Brazilians' level of English proficiency once only about 5\% of Brazilians are said to be fluent in English. Nonetheless, this policy does not seem to encourage multilingualism and there are few hopes of improving EFL education because of the general belief that "nobody learns a foreign language well at school" (Tilio, 2014). In order to "really learn English" those who can afford to go to private language institutes that focus on English as an international rather than as a foreign language with an instrumental, rather than a formative role. As a result, people who cannot afford to go to private language institutes will be excluded thus increasing social inequalities and creating a social gap (Finardi, 2014).

Yet, as these private language institutes, mainly franchised companies, tend to see English teaching as a matter of instruction and not so much as linguistic education, students are more likely to reproduce hegemony discourses and ideologies being less likely to critically appropriate the language. Finardi (2014) invites Brazilians to overcome the myth of having to speak like the native speaker by "appropriating" English, empowering Brazilian speakers of English and English teachers. To achieve this, language education is necessary and it can be predicted that to bring about this education in times of identity, linguistic and cultural hybridism coupled with affordances of the "digitalized" society is bound to create some form of paradigm disruption. 
As the number of English speakers has grown significantly, "multiple Englishes" (Cope \& Kalantzis, 2000; Finardi \& Ferrari, 2008) have sprouted through linguistic and cultural contact. In this scenario, language education needs to consider the hybridity in language and in the classroom to question and critique hegemonic and neo-liberal discourses rooted in EFL. Mattos (2015) describes the tension between two attitudes regarding education: the globalizing one, which reproduces hegemonic power relations and ideologies, and the localizing one that seeks to empower students to defy hegemony and transform their locality. In this sense it is necessary to ask how English teacher education programs approach English with its ideological aspects in the education of critical citizens.

For a long time, we have tried to standardize schools, behaviors and students' and teachers' performance (Bohn, 2013), excluding those that do not conform to the norm imposed by hegemony. In the case of EFL teaching, native speakers of English were seen as the "model" (Medgyes, 1994). As a first step to break this paradigm in EFL education, Duboc (2015) suggests it is important to discuss views of languages in general and of English, as the global language, in particular once teachers' beliefs about the language and their profession affect EFL education directly (Finardi \& Prebianca, 2016). Finardi and Prebianca (2016) carried a survey to investigate the beliefs of pre-service English teachers in Brazil regarding their profession. Results of their study showed that most Brazilian EFL teachers see themselves as instructors rather than as educators. The aforementioned authors relate this result to the foreignity associated with English. Other factors mentioned by the authors and that may contribute to that result are the insufficient number of weekly hours dedicated to the teaching of foreign languages at schools, the underestimation of the subject by school directors and the hiring of native speakers of English who do not have proper professional qualifications to teach languages and that were hired solely on the basis of their "fluency" (Finardi \& Prebianca, 2016). This belief that pre-service English teachers have shown in that study is a result of their prior experience as English learners and, as such, EFL teacher education is required to develop pre-service teachers' ability to critically reflect on their experience in order to question and reconstruct those beliefs. However, it seems that EFL pre-service teacher education in Brazil is more focused on discussions on what and how to do in class rather than on why teachers do what they do. Consequently, the new teacher will work mainly applying methods to teach English as a tool for improving students' professional skills (Ialago \& Duran, 2008) without realizing that English teachers play a key role in the mediation of the global and the local contexts by deciding which teaching approach(es) and means to use (Mattos, 2015). Accordingly, it is necessary to recognize the non-neutrality of these professionals whose choices may determine whether or not students will be empowered by the English language to live the global and local dimensions of their reality (Finardi, 2017). If the teacher sees his/her practice as apolitical and neutral, students can be led to reject the language or to accept it without criticism, thus underestimating its own locality (Mattos, 2015).

One issue that emerges from the critical language education described above is how to reconcile the teaching of a language with both a critical (empowering) and an instrumental (purely linguistic) focus. We can relate the tension between the instrumental versus the empowering roles of language teaching with Warschauer's view of the restricted - broad 
access to technology (Warschauer, 2003). Though only the broad (critical) access to technology leads to social capital development, the restricted (instrumental) access is necessary for the broad access to emerge. Can we say the same about language education? Should language teachers enable one first so as to foster the other? Can these two aspects of language education be reconciled and taught in tandem?

Going back to the discussion on technology, another issue to consider is the integration of NICT in teacher education. Monte Mór (2012) draws attention to the high rate of Brazilian school dropouts which may mean that schools are not aligned with a digital epistemology. Her research found that Brazilian teacher education programs seem to encourage a rather linear and segmented interpretation by following pre-established conventions through a content-focused approach in a traditional epistemology. Still regarding English teacher education in Brazil, several authors (Finardi et al., 2013; Fadini, 2016; Finardi \& Dalvi, 2013; Finardi \& Prebianca, 2014; Finardi \& Porcino, 2015) state that it does not reflect the changes in social processes, especially regarding the use of NICT in pedagogical practices. According to these authors, NICT are already part of students' daily lives permeating almost all their activities while at school and in academic contexts, NICTs are still seen and used mainly in a peripheral way (Finardi \& Porcino, 2014).

Teixeira and Finardi (2013), for example, investigated the integration of NICT in the pedagogical practice of university professors concluding that the lack of integration of NITC into their pedagogical practice was not justified by the restricted access to NICT, but rather by the use made of NICT, in other words, by the lack of ample (critical use) use of technology. Paiva (2013) reminds us that teachers/professors should give the example of NITC integration, especially in the case of teacher education programs. Unfortunately, this is not what seems to happen as shown in an analysis of an English Language Teaching Program in Brazil (Fadini, 2016).

Another resistance factor for the integration of NICT in education is related to the disruptions in student-teacher relations (Bohn, 2013). In the infoera the teacher is no longer the only source of information. In order to be able to teach, it is necessary to have not only technical skills to use digital technology, but also and more importantly, digital literacy to navigate through the practical, cultural and critical aspects of education and technology (Ferraz, 2014). Rojo (2009) states that digital media generates new social practices and the school needs to prepare students to exercise their citizenship in and through them. Paiva (2013) suggests that all teachers should master the necessary tools to foster collaboration and empowerment among students and adds that teacher education programs should provide this training. According to Lankshear and Knobel (2007), NICT can mean transformation in literacy practices only if they take into account their values and not only their tools.

Therefore, teachers find themselves at a very challenging and maybe uncomfortable situation, where they have to be teachers and students at the same time in order to learn these new values from their own students because most of them already live the new ethos (2007). Teachers who are able to understand their own identity and culture as hybrid are more likely to promote a better integration and enhancement of differences between each other but also within oneself. In this sense, Merlo and Ferraz (2016) argue that critical thinking should be 
promoted by EFL teacher education programs not only related to English but also to students' and their cultures. As Pennycook (2006) says, identity is formed through linguistic performance, therefore, EFL classroom interactions and EFL teacher education environments are part of students' and teacher's continuous identity constructions. So, global discourses reverberated in these contexts, many times through methodologies and materials produced by hegemonies, must be critically looked at through local lenses. As a result, EFL may represent a possible way to subvert the standardization of schools opening up space to legitimize local knowledge (Maciel, 2013). With that aim, we agree with Gimenez and Cristovão (2004) when they suggest a curricular review of EFL teacher education programs to better articulate the relationship between the participants in the community of practice once the inclusion of these voices may narrow the gap between the academia and the school (Moreira, 2015), between theory and practice in education (Finardi \& Dalvi, 2012) and between global and local contexts.

\section{Conclusions}

In the complex conjuncture of globalization, we understand that the phenomena of cultural hybridization and the emergence of NICT directly affect language education in general and EFL teacher education in particular. It is necessary to break with some deep-rooted paradigms that view linguistic education as instrumental, neutral and apolitical by offering opportunities to discuss the ideology of hegemonic discourses. In order to practice an ecology of knowledge (Santos, 2006), universities should strive to perceive other points of view, listening to the excluded and invisible voices in their locality as a way to fight against the homogenization of local practices according to global hegemonic perspectives. For this, and according to Fadini (2016), we suggest a review of EFL teacher education programs' curricula in order to promote teacher education in a critical, reflexive and digitally literate fashion so as to equip teachers to provide an appropriate language education and mediation for the current context of new social practices.

\section{Acknowledgement}

This study was supported by Brazilian National Council for the Improvement of Higher Education (CAPES- author 1) and FAPES (author 2). The authors wish to thank comments of anonymous reviewers which greatly helped to improve the text.

\section{References}

Appadurai, A. (2000). Grassroots Globalization and the Research Imagination. Public Culture, 12(1), 1-19. https://doi.org/10.1215/08992363-12-1-1

Bauman, Z. (2005). Liquid Life. Cambridge: Polity Press.

Bhabha, H. K. (2013). O local da cultura. Belo Horizonte: UFMG.

Blommaert, J (2010). The sociolinguistics of globalization. Cambridge: Cambridge University Press. https://doi.org/10.1017/CBO9780511845307

Bohn, H. I. (2013). Ensino e aprendizagem de línguas: os atores da sala de aula e a necessidade 
de rupturas. In L. P. Moita Lopes (Ed.), Linguística aplicada na modernidade recente: festchrift para Antonieta Celani (pp. 79-98). São Paulo: Parábola.

Bourdieu, P. (1991). Language and symbolic power. Cambridge: Harvard University Press.

Bruns, A. (2006). Towards produsage: Futures for user-led content production. In F. Sudweeks, H. Hrachovec, \& C. Ess (Eds.), Proceedings Cultural Attitudes towards Communication and Technology 2006 (pp. 275-284). Murdoch: Murdoch University.

Burke, P. (2003). Hibridismo cultural. São Leopoldo: Ed. da Unisinos.

Canagarajah, A. S. (Ed.). (2005). Reconstructing local knowledge, reconfiguring language studies. In A. S. Canagarajah (Ed.), Reclaiming the local in language policy and practice (pp. 3-24). New Jersey: Lawrence Erlbaum.

Canclini, N. G. (2008). Culturas híbridas: estratégias para entrar e sair da modernidade. Translated by Heloísa Pezza Citrão e Ana Regina Lessa. São Paulo: Universidade de São Paulo.

Casotti, J., \& Finardi, K. R. (2016). Abordagens Inclusivas No Ensino De Línguas : Desafios Para A Formação Docente. Revista (Con)Textos Linguísticos (UFES), 10, 63-76.

Castells, M. (2016). A Sociedade em Rede (16th ed.). São Paulo: Paz e Terra.

Cevasco, M. E. (2006). Hibridismo cultural e globalização. ArtCultura, 8(12), 132-138.

Cooppan, V. (2004). Ghosts in the disciplinary machine: the uncanny life of world literature. Comparative literature studies, 41(1), 10-36. https://doi.org/10.1353/cls.2004.0001.

Cope, B., \& Kalantzis, M. (2000). Multiliteracies: Literacy learning and the design of social futures. London: Routledge.

Crystal, D. (2003). English as a Global Language (2nd ed.). Cambridge: Cambridge University Press. https://doi.org/10.1017/CBO9780511486999

Duboc, A. P. M. (2015). Letramentos críticos nas brechas da sala de aula de línguas estrangeiras. Jundiaí: Paço Editorial.

Erling, E., \& Seargeant, P. (2013). Introduction: English and Development. In E. Erling, \& P. Seargeant (Eds.), Policy, Pedagogy and Globalization (pp. 1-21). Bristol: Multilingual Matters.

Fabrício, B. F. (2006). Linguística Aplicada como espaço de "desaprendizagem" redescrições em curso. In L. P. Moita Lopes (Ed.), Por uma linguística Indisciplinar (pp. 45-66). São Paulo: Parábola Editorial.

Fadini, K. A. (2016). Formação Inicial de Professores de Inglês do e para o Século XXI: os papéis da língua inglesa e da tecnologia digital (Master's Thesis). Retrieved from http://www.linguistica.ufes.br/pt-br/pos-graduacao/PPGEL/lista-de-discentes-egressos

Ferraz, D. (2010). EELT - Education through English Language Teaching in a Brazilian 
Technical School. Revista Crop, 15, 102-119.

Ferraz, D. M. (2014). Novos letramentos e educação de línguas estrangeiras: problematizações e desafios. In P. R. Stella, I. Cavalcanti, R. Tavares, \& S. Ifa (Eds.), Transculturalidade e De(s)colonialidade nos Estudos em Inglês no BraZil (pp. 53-83). Maceio: Edufal.

Finardi, K. R. (2014). The Slaughter of Kachru's Five Sacred Cows in Brazil: Affordances of the Use of English as an International Language. Studies in English Language Teaching, 2, 401-411.

Finardi, K. R. (2016). Globalization and English in Brazil. In K. R. Finardi (Ed.), English in Brazil: views, policies and programs (pp. 15-36). Londrina: EDUEL.

Finardi, K. R. (2017). What can Brazil Learn from Multilingual Switzerland and its Use of English as a Multilingua Franca. Acta Scientiarum (UEM), 39(2), 219-228. https://doi.org/10.4025/actascilangcult.v39i2.30529.

Finardi, K. R., \& Dalvi, M. A. (2012). Encurtando as Distâncias entre Teoria-Prática e Universidade-Escola no Ensino de Línguas e na Formação de Professores. Intersecções (Jundiai), 5, 115-127.

Finardi, K. R., \& Dalvi, M. A. (2013). Crenças de professores de línguas sobre a formação inicial e continuada. Glauks (UFV), 13, 113-134.

Finardi, K., \& França, C. (2016). O inglês na internacionalização da produção científica brasileira. Revista Intersecções, 19, 234-250.

Finardi, K. R., \& Porcino, M. C. (2014). Tecnologia e Metodologia no Ensino de Inglês: Impactos da Globalização e da Internacionalização. Ilha do Desterro, 66, 239-283. https://doi.org/10.5007/2175-8026.2014n66p239

Finardi, K. R., \& Porcino, M. C. (2015). O Papel do Inglês na Formação e na Internacionalização da Educação no Brasil. Revista Horizontes de Linguistica Aplicada, 14, 109-13.

Finardi, K. R., \& Porcino, M. C. (2016). Facebook na ensinagem de inglês como língua adicional. In J. Araújo, \& V. Leffa. (Eds.), Redes sociais e ensino de língua: o que temos de aprender (pp. 99-115). São Paulo: Editora Brasileira Comercial.

Finardi, K. R., \& Prebianca, G. V. V. (2014). Políticas linguísticas, internacionalização, novas tecnologias e formação docente: um estudo de caso sobre o curso de Letras Inglês em um universidade federal. Leitura (UFAL), 1, 129-154.

Finardi, K. R., \& Prebianca, G. V. V. (2016). Ensino Crítico de Inglês e Formação Docente na Contemporaneidade. Atos de Pesquisa em Educação (FURB), 11, 549-571. https://doi.org/10.7867/1809-0354.2016v11n2p549-571

Finardi, K. R., Prebianca, G. V. V., \& Momm, C. F. (2013). Tecnologia na Educação: o caso da Internet e do Inglês como Linguagens de Inclusão. Cadernos do IL, 46, 2013, 193-208. 


\section{Macrothink}

Education and Linguistics Research

ISSN 2377-1356 2018, Vol. 4, No. 1

Finardi, K. R., Santos, J. M., \& Guimaraes, F. (2016). A Relação entre Línguas Estrangeiras e o Processo de Internacionalização: Evidências da Coordenação de Letramento Internacional de uma Universidade Federal. Interfaces Brasil/Canadá, 16, 233-255.

Finardi, K. R., \& Tyler, J. (2015). The Role of English and Technology in the Internationalization of Education: Insights from the Analysis of MOOCs. In L. Gómez Chova, A. López Martinez, \& I. Candel Torres (Eds.), EDULEARN15 Proceedings (pp. 11-18). Valencia: IATED Academy.

Finardi, K., \& Ferrari, L. (2008). Reflecting on the English (es) taught in Brazil. Revista Crop, $13,205-214$.

Fleuri, R. M. (2003). Intercultura e educação. Rev. Bras. Educ., 23, 16-35. https://doi.org/10.1590/S1413-24782003000200003

Freire, P. (2011). Pedagogia do Oprimido (50th ed.). Rio de Janeiro: Paz e Terra.

Gimenez, T. N., \& Cristovao, V. L. L. (2004). Derrubando paredes e construindo pontes: formação de professores de língua inglesa na atualidade. Rev. bras. linguist. apl., Belo Horizonte, 4(2), 85-95. https://doi.org/10.1590/S1984-63982004000200005

Hall, S. (1992). The questions of cultural identity. In S. Hall, \& T. Mcgrew (Eds), Modernity and its Futures (pp. 274-316). Oxford: Polity Press.

Hall, S. (2013). Da diáspora: identidades e mediações culturais (2nd ed.). Belo Horizonte: Ed. da UFMG. https://doi.org/10.5565/rev/da.153

Ialago, A. M., \& Duran, M. C. G. (2008). Formação de professores de inglês no Brasil. Revista Diálogo Educacional, 8(23), 55-70. https://doi.org/10.7213/rde.v8i23.3967

Jenkins, J. (2007). English as a Lingua Franca: attitude and identity. Oxford: Oxford University Press.

Jenkins, J. (2013). English as a lingua franca in the international university: The politics of academic English language policy. Routledge.

Kern, D. (2011). O conceito de hibridismo ontem e hoje: ruptura e contato. MÉTIS: história \& cultura, 3(6), 53-70.

Knight, J., \& de Wit, H. (Ed). (1997). Internationalization of higher education in Asia Pacific countries. Amsterdam: European Association for International Education.

Kumaravadivelu, B. (2006). A linguística aplicada na era da globalização. In L. P. Moita Lopes (Ed.), Por uma linguística Indisciplinar (pp. 129-148). São Paulo: Parábola Editorial.

Lankshear, C, \& Knobel, M. (2003). New Literacies: Changing Knowledge and Classroom Research. Buckingham: Open University Press.

Lankshear, C.; Knobel, M. (2007). Researching new literacies: Web 2.0 practices and insider perspectives. E-Learning and Digital Media, 4(3), 224-240. https://doi.org/10.2304/elea.2007.4.3.224 


\section{MInstitute ${ }^{\text {Mink }}$}

Lévy, P. (2000). Cibercultura (2nd ed.). Translated by Irineu da Costa. São Paulo: Editora 34.

Maciel, R. F. (2013). Políticas Linguísticas, Conhecimento Local e Formação de Professores de Línguas. In C. Nicolaides, K. A. Silva, R. Tílio, \& C. H. Rocha (Eds.), Política e Políticas Linguísticas (pp. 237-261). Campinas: Pontes Editores.

Mattos, A. M. A. (2015). Ensino de inglês como Língua estrangeira na escola pública: letramentos, globalização e cidadania. Jundiaí: Paço Editorial, 197-239.

Medgyes, P. (1994). The non-native teacher. London: Macmillan.

Merlo, M. C. R., \& Ferraz, D. M. (2016). Letramentos e formação docente para o ensino de inglês. In M. M. Tomazi, L. H. P. Rocha, \& D. M. Ferraz (Eds.), Estudos linguísticos: descrição, texto, discurso e ensino (pp. 265-278). Vitória: Programa de Pós-graduação em Estudos Linguísticos.

Mignolo, W. D. (2003). Histórias locais-projetos globais: colonialidade, saberes subalternos e pensamento liminar. Belo Horizonte: UFMG.

Moita Lopes, L. P. (2006). Linguística aplicada e vida contemporânea. In L. P. Moita Lopes, (Ed.), Por uma Linguística Aplicada Indisciplinar (pp. 85-105). São Paulo: Parábola Editorial.

Monte Mór, W. M. (2009). Foreign languages teaching, education and the new literacies studies: expanding views. In G. R. Gonçalves, S. R. G. Almeida, V. L. M. O. Paiva, \& A. S. Rodrigues-Júnior (Eds.), New Challenges in Language and Literature (pp. 177-189). Belo Horizonte: UFMG.

Monte Mór, W. M. (2012). Linguagem tecnológica e educação. Em busca de práticas para uma formação crítica. In I. Signorini, \& R. S. Fiad (Eds.), Ensino de língua. Das reformas, das inquietações e dos desafios (pp. 181-190). Belo Horizonte: UFMG.

Moreira, A. F. B. (2015) A formação de professores e o aluno das camadas populares: subsídios para debate. In N. Alves (Ed.) Formação de professores: pensar e fazer (pp. 39-55). São Paulo: Cortez.

Nicolelis, M. (2011). Muito além do nosso eu: a nova neurociência que une cérebro e máquinas e como ela pode mudar nossas vidas. São Paulo: Editora Companhia das Letras.

Paiva, V. L. M. O. (2001). A www e o ensino de inglês. Revista Brasileira de Linguística Aplicada, 1(1), 93-116. https://doi.org/10.1590/S1984-63982001000100006.

Paiva, V. L. M. O. (2013). A formação do professor para uso da tecnologia. In K. A. Silva, F. G. Daniel, S. M. Kaneko-marques, \& A. C. B. Salomão (Eds.), A formação de professores de linguas: Novos Olhares (pp. 209-230). Campinas, SP: Pontes Editores.

Pennycook, A. D. (2006). Uma linguística aplicada transgressiva. In L. P. Moita Lopes (Ed.). Por uma linguística Indisciplinar (pp. 67-84). São Paulo: Parábola Editorial.

Portes, A. (2000). Capital social: origens e aplicações na sociologia contemporânea. 


\section{Macrothink}

Sociologia, Problemas e Práticas, 33, 133-158.

Prensky, M. (2001). Digital natives, digital immigrants, part II: do they really think differently? On the Horizon, 9(6), 1-6. https://doi.org/10.1108/10748120110424843

Rada, J. (2004). Oportunidades e riscos das novas tecnologias para a educação. In J. C. Tedesco (Ed.), Educação e novas tecnologias: esperanças ou incertezas? (pp. 109-119). Translated by Cláudia Berlier, Silvana Cobucci Leite. São Paulo: Cortez.

Rassool, N. (2007). Global issues in language, education and development: Perspectives from postcolonial countries. Clevedon: Multilingual Matters.

Robertson, R. (1995). Glocalization: Time-space and homogeneity-heterogeneity. Global modernities, 2, 25-45. https://doi.org/10.4135/9781446250563.n2

Rojo, R. (2009). Letramentos múltiplos, escola e inclusão social. São Paulo: Parábola Editorial.

Santos, B. S. (2006). A gramática do tempo: Para uma nova cultura política. São Paulo: Cortez.

Santos, B. S. (2007). Para além do pensamento abissal: das linhas globais a uma ecologia de saberes. Novos estudos-CEBRAP, 79, 71-94.

Taquini, R., Finardi, K. R., \& Amorim, G. B. (2017). English as a Medium of Instruction at Turkish State Universities. Education and Linguistics Research, 3(2), 35-53. https://doi.org/10.5296/elr.v3i2.11438

Teixeira, D., \& Finardi, K. R. (2013). TICs no Ensino Presencial: Evidências de um Curso de Formação Continuada na Universidade Federal do Espírito Santo. Revista (Con)Textos Linguísticos (UFES), 7, 79-96.

Tilio, R. C. (2014). Língua Estrangeira Moderna na Escola Pública: possibilidades e desafios. Educação \& Realidade, 39(3), 925-944. https://doi.org/10.1590/S2175-62362014000300016

United Nations Development Programme. Human Development Report Office. (1999). Human Development Report: Background papers. Human Development Report Office, United Nations Development Programme.

Warschauer, M. (2003). Social capital and access. Universal access in the Information Society, 2(4), 315-330. https://doi.org/10.1007/s10209-002-0040-8

Warschauer, M. (2004). Technology and social inclusion: Rethinking the digital divide. Cambridge: MIT Press. 
Notes

Note 1. Figurative term used to refer to something that resembles an interconnected, subterranean network of roots and as such is interconnected and non-hierarchical.

Note 2. For more examples of unequal opportunities afforded by globalization, please check the United Nations' Human Development Report (1999, p. 31).

Note 3. The term "glocal" was first used in the field of Management/Marketing and later expanded to other areas such as Sociology (Robertson, 1995).

Note 4. Brazilian sign language also has the status of an official language though it is neither spoken nor known by most Brazilians.

\section{Copyright Disclaimer}

Copyright reserved by the author(s).

This article is an open-access article distributed under the terms and conditions of the Creative Commons Attribution license (http://creativecommons.org/licenses/by/3.0/). 